\title{
De match tussen mens en machine
}

\author{
Bas ter Weel
}

\section{Inleiding}

Technologische vooruitgang beïnvloedt de verdeling van werk tussen mens en machine. Vanaf 1980 heeft informatie- en communicatietechnologie (ICT) de verhoudingen op de arbeidsmarkt veranderd. Er zijn nieuwe banen ontstaan en andere banen zijn verdwenen. Dit heeft de vraag naar arbeid veranderd, omdat sommige taken door computers zijn overgenomen, terwijl andere taken juist complementair zijn aan de nieuwe technologie. Hierdoor zijn de arbeidsmarktkansen voor bepaalde groepen verslechterd, omdat er aanpassingen plaatsvinden die impact hebben op de kans op werk en de loonverdeling. In de jaren tachtig en negentig stonden de relatieve lonen van vooral laagopgeleide werknemers onder druk als gevolg van automatisering in fabrieken en een beweging naar een meer op diensten gerichte economie. Sinds de beginjaren van de 21ste eeuw lijken vooral mensen met een mbo-opleiding te maken te hebben met veranderingen. ${ }^{1}$ Deze ontwikkelingen zijn in veel landen zichtbaar, ook in Nederland.

Deze bijdrage beschrijft eerst hoe computertechnologie de verdeling van werk tussen mens en machine in de afgelopen decennia heeft veranderd. Vanaf 1980 heeft informatie- en communicatietechnologie (ICT) de verhoudingen op de arbeidsmarkt veranderd. Er zijn nieuwe banen ontstaan en andere banen zijn verdwenen. Websitebouwers en softwareontwikkelaars zijn voorbeelden van zulke nieuwe banen. De vaardigheden die worden gevraagd, zijn ook gewijzigd, omdat computers een aantal taken hebben overgenomen, terwijl er ook nieuwe taken zijn bijgekomen (zie bijvoorbeeld Autor, Levy \& Murnane, 2003). Automatisering heeft bij banken geleid tot een geringere vraag naar administratieve taken, maar tot een grotere vraag naar advies over complexe financiële producten, zoals hypotheken en beleggingsproducten (zie bijvoorbeeld Groot \& De Grip, 1991; Autor, Levy \& Murnane, 2002). Ook zijn er nieuwe problemen ontstaan, zoals cybercrime en malware, die tot nieuwe bedrijvigheid leiden.

Een tweede doel van deze bijdrage is om een aantal recente trends op de Nederlandse arbeidsmarkt in beeld te brengen. De beloning van verschillende beroepen verandert. In de jaren tachtig en negentig stonden de relatieve lonen van vooral laagopgeleide werknemers onder druk als gevolg van automatisering in fabrieken en een beweging naar een meer op diensten gerichte economie. Sinds de beginjaren van de 21ste eeuw lijken vooral mensen met een gemiddelde opleiding (in Nederland een mbo-opleiding) te maken te hebben met veranderingen als gevolg van bijvoorbeeld automatisering van administratieve en technische processen die het voor consumenten steeds eenvoudiger maken om zelf online zaken te regelen.

* Prof. dr. Bas ter Weel is onderdirecteur van het Centraal Planbureau en hoogleraar economie aan de Universiteit Maastricht. www.cpb.nl/medewerkers/bas-ter-weel. b.ter.weel@cpb.nl 
Ook hoogopgeleide werknemers (gedefinieerd vanaf hbo) zijn niet immuun voor veranderingen. Het opleidingsniveau van de wereldbevolking neemt toe en de mogelijkheden om bepaalde taken uit te besteden naar het buitenland is door de communicatietechnologie vergroot. Taken worden steeds vaker uitgevoerd op plaatsen waar dat het meest efficiënt is. Het editen van wetenschappelijke publicaties geschiedt bijvoorbeeld in toenemende mate in India. Door slimme zoekmachines is het voor juristen ook steeds eenvoudiger om wetteksten uit te zoeken om vragen te beantwoorden, waardoor ook hier de vraag verschuift. ${ }^{2}$ Aan de aanbodkant van de arbeidsmarkt zien we dat de Nederlandse beroepsbevolking steeds hoger opgeleid is. In 1996 bestond de grootste groep op de Nederlandse arbeidsmarkt uit mensen met een mbo-opleiding, nu zijn dat hbo'ers. En ook binnen het mbo is een verschuiving richting mbo4 gaande.

\section{Hoe technologie het werk verandert}

Een afwashulp in een restaurant voert zes taken uit. Hij ruimt de tafel af, maakt een sopje met zeep, wast de glazen en borden schoon, spoelt de vaat af met schoon water, droogt af en zet het servies terug in de kast. De afwasmachine heeft vier taken overgenomen, maar de eerste en laatste taak worden door de mens uitgevoerd. Dit zal voorlopig niet veranderen. Er is zelfs een taak voor de afwashulp bijgekomen: het in- en uitpakken van de afwasmachine. Het effect van deze technologische verandering is dat er in eerste instantie minder afwashulpen nodig zijn omdat de afwasmachine efficiënter en goedkoper werkt. En voor de taken die overblijven, is waarschijnlijk minder tijd nodig. De prijs van een maaltijd in het restaurant zal hierdoor dalen, waardoor er meer maaltijden worden genuttigd en de vraag naar afwashulpen (en afwasmachines) weer zou kunnen stijgen. Technologie verandert de manier waarop taken worden uitgevoerd en het aantal taken dat wordt uitgevoerd, waarbij de machine soms taken overneemt en soms de mens ondersteunt.

\subsection{Computertechnologie}

De voor de mens inmiddels onevenaarbare rekenkracht van computers komt tot uitdrukking in het feit dat ze regels foutloos en snel uitvoeren. Daarnaast zijn de kosten van computertechnologie in de afgelopen decennia drastisch gedaald. Naar het fenomeen van toenemende kracht en dalende prijzen wordt weleens gerefereerd als 'Moore's law'. Deze wet stelt dat het aantal transistors in een geïntegreerde schakeling door de technologische vooruitgang elke twee jaar verdubbelt. Computers hebben daarom een aantal taken van de mens overgenomen. Voor deze overname zijn twee condities van belang: alle informatie die nodig is om een taak uit te voeren moet worden geïdentificeerd en vastgelegd in regels die een computer kan volgen, en het verwerken van informatie moet kunnen worden vastgelegd in computercodes.

Aan beide condities kan worden voldaan door middel van een deductieve regel die is gebaseerd op bijvoorbeeld het 'if, then'-principe. Inchecken op een vliegveld gaat op deze manier. Als het paspoortnummer overeenkomt met een ticketnum- 
mer dat door de computer wordt herkend, wordt een boardingpass geprint. Zo niet, dan wordt de passagier verwezen naar een balie voor hulp. Daarnaast zijn inductieve regels mogelijk die op basis van statistische verbanden patronen herkennen. Deze informatie kan door de computer worden toegepast op concrete waarnemingen, maar vergt wel bijstelling. Van een stel dat een hypotheek wil afsluiten, wordt een risicoprofiel opgesteld op basis waarvan een voorstel uit het model rolt. De adviseur gebruikt dit advies voor een passende hypotheek. Het is wel van belang dat rekening wordt gehouden met nieuwe informatie (die de computer niet zomaar kent), zoals een aanscherping van de hypotheekregels of het sentiment in tijden van crisis, met niet-verneembare of te kwantificeren kenmerken van het stel en de markt en met diverse vormen van meetfouten die kunnen optreden bij dit soort statistische modellen.

De manier waarop computertechnologie wordt benut, heeft de verdeling van taken tussen computer en werknemer veranderd en is tevens van invloed op productieprocessen, die steeds vaker in mondiale waardeketens zijn opgedeeld (zie bijvoorbeeld Timmer e.a., 2014). Computers zijn ingezet voor taken waarin ze efficiënter en goedkoper zijn dan de mens en daar waar ze het werk van mensen aanvullen.

\subsection{Robots}

Het afgelopen jaar is veel gediscussieerd over robotisering als nieuwste uiting van de opkomst en diffusie van ICT. De beelden appelleren vaak aan sciencefictionachtige situaties waarin robots de mens buitenspel zetten. Voordat we ons zorgen maken over de mogelijke impact van robots, is het goed om te bezien waartoe robots in staat zijn en wat de ontwikkelingen tot nu toe zijn. ${ }^{3}$ Er zijn drie generaties robots.

De eerste generatie voert op een mechanische en precieze wijze een gestandaardiseerde taak uit. Dit wordt trajectory control genoemd. Het gros van de huidige robots is van dit type. De moderne autofabriek is daar een voorbeeld van. Onderdelen worden op een soort lopende band aan elkaar gelast en in elkaar geschroefd, met als resultaat een complete auto. Ook het bekende setje van drie paprika's (groen, geel en rood) wordt op een lopende band door drie grijparmen in goede banen geleid, waarbij de robotarm de paprika's ook nog met dezelfde kant naar boven weet te leggen. Allemaal efficiënt en grote productiviteitswinst. Nadeel van deze robots is dat ze gevaarlijk zijn. Er moet een kooi omheen om ongelukken te voorkomen. De arm kent het onderscheid tussen een paprika of auto-onderdeel en een menselijke vinger of hand (die een paprika recht willen leggen) niet, met alle gevolgen van dien. Ook spietsen de robotvingers nog wel eens een paprika, waardoor het productieproces moet worden stopgezet en opnieuw opgestart.

De tweede generatie robots is tot meer in staat. Deze generatie wordt ook wel als intelligent control gelabeld. Deze robots houden rekening met de omgeving waarin ze zich bevinden. Het zijn apparaten die een kopje koffie kunnen brengen zonder te morsen, die mensen met een dwarslaesie ondersteunen met een soort korset of met een prothesehand die begrijpt dat een framboos net iets anders moet worden aangepakt dan een steen. Het verschil met de eerste generatie robots is dat deze robots kunnen 'zien' en in staat zijn hun acties aan te passen aan de omgeving. In 
die zin zijn ze dus intelligent. De toepassing van dit soort robots neemt vooral in de medische hoek een vlucht.

Een derde ontwikkeling is human enhancement. Onder deze groep robots vallen bijvoorbeeld de deels zelfrijdende auto's. De robot verbetert de menselijke handeling en voorkomt domme acties. Deze robots kunnen situaties min of meer zien aankomen en handelen preventief in plaats van reactief. Als er een obstakel op de weg ligt, zal een zelfsturende auto daar soepel omheen rijden. De mens wordt ondersteund, maar moet wel opletten. De vergelijking met een paard wordt wel eens gemaakt. Een paard loopt en ontwijkt hobbels op de weg, maar de berijder moet wel aangeven waar het paard naartoe moet lopen, in welk tempo dat moet gebeuren en over welke balken het moet springen. Opnieuw zijn hier ook medische toepassingen denkbaar, zoals een robot die een patiënt uit bed tilt en daarbij rekening houdt met de gesteldheid van de patiënt.

\subsection{Mens en machine}

Banen bestaan uit een set taken, zoals het voorbeeld van de afwashulp aangeeft. De manier waarop deze taken worden georganiseerd, hangt van een aantal factoren af. Voor de werknemer is het vooral een afweging van coördinatiekosten en productiekosten. Als het eenvoudig is veel kleine taken zelf te doen, is het niet de moeite waard om taken te verdelen tussen verschillende mensen of tussen mens en machine, ook al zouden daar kosten mee bespaard kunnen worden. Overleg en controle zouden bij een verdeling van taken duurder kunnen uitpakken dan deze besparing. ${ }^{4}$

Technologie verandert deze afweging. Dit kan twee kanten op gaan. Computers maken het eenvoudiger om routinematige taken zelf te doen, zoals het tikken van deze tekst, maar vereenvoudigen ook de afstemming van het werk tussen mens en machine. Dit geldt niet alleen voor de afstemming tussen een pc en de mens, maar ook voor die tussen mens en robot. Indien taken kunnen worden afgesplitst van een individuele baan, kunnen ze mogelijk door het bedrijf worden uitbesteed. Binnenshuis uitvoeren maakt afstemming makkelijker en de kwaliteit kan worden gecontroleerd, terwijl uitbesteden kosten drukt en risico's spreidt. Tevens kunnen taken die door het bedrijf worden uitbesteed ook in het buitenland worden uitgevoerd. Ook nu zijn er voordelen verbonden aan het regionaal clusteren van activiteiten, maar kan het ook van belang zijn om dicht bij de (buitenlandse) klant te zitten.

Autor en anderen (2003) maken een onderscheid tussen routinematige taken en niet-routinematige taken. Routinematige taken worden op een standaardwijze uitgevoerd, terwijl niet-routinematige taken aanpassingsvermogen van de werknemer vergen. Routinematige taken voldoen in grotere mate aan de voorwaarden om door machines/computers te worden uitgevoerd. Niet-routinematige taken vragen creativiteit, probleemoplossend vermogen, flexibiliteit en andere vaardigheden, waarbij de gewenste acties van de werknemer niet vooraf te bepalen zijn. Handmatige taken zijn uitvoerende taken die fysieke inspanning vergen. Voorbeelden zijn het besturen van een vrachtwagen en het schoonmaken van een vloer. Analytische taken vergen voornamelijk hersenactiviteit en niet zozeer 


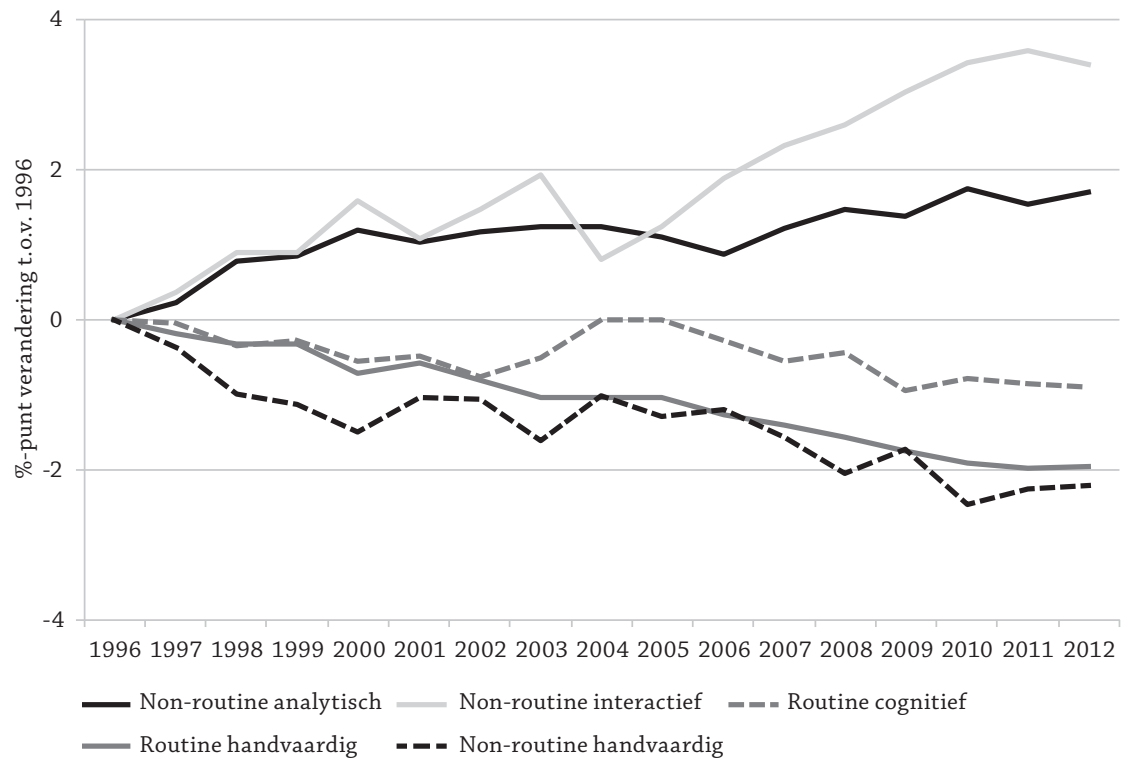

Bron: Eigen berekeningen op basis van de Enquête Beroepsbevolking (CBS) en de beroepenindeling van Den Butter en Mihaylov (2013)

Figuur 1 Veranderingen in de werkgelegenheid in Nederland, gemeten in taken, 1993-2009

fysieke activiteit. Het analyseren van een röntgenfoto is een voorbeeld van deze taken. Ten slotte bestaat er een categorie interactieve taken. ${ }^{5}$

Figuur 1 plot de werkgelegenheidsontwikkeling van beroepen waarin vijf taken in verschillende mate voorkomen in Nederland (1993-2009). De indeling in taken is gebaseerd op de Standaard Beroepenclassificatie 1992 van het CBS en samengesteld door Den Butter en Mihaylov (2013). De figuur laat de werkgelegenheidsontwikkeling vanaf 1993 zien. Het werkgelegenheidsaandeel van beroepen met routinematige taken is afgenomen ten koste van beroepen met meer nietroutinematige taken. Deze veranderingen vinden voor een deel binnen beroepen plaats. Natuurlijk zullen er beroepen verdwijnen (wie kent de lantaarnopsteker nog), maar computertechnologie neemt routinematige taken binnen beroepen over, zoals hieronder wordt beschreven in een aantal casestudies. Wat tevens opvalt is dat beroepen met veel niet-routinematige handmatige taken ook negatieve werkgelegenheidsgroei laten zien. Deze ontwikkelingen zijn ook in andere landen zichtbaar, zoals de Verenigde Staten (Autor, Katz \& Kearney, 2006), Duitsland (Spitz-Oener, 2006) en Engeland (Goos \& Manning, 2007).

\subsection{Casestudies}

Casestudies laten zien dat vooral de vraag naar handmatige routinematige taken is gedaald en dat deze taken deels zijn overgenomen door computertechnologie. 
Het gaat hier vooral om repeterende taken die eenvoudig in computercode kunnen worden beschreven, maar ook om handmatige niet-routinematige taken, zoals eenvoudige diensten, en de meer analytische routinematige taken, zoals boekhouden. Daarnaast blijkt computertechnologie de mens aan te vullen en productiever te maken. De meeste veranderingen vinden binnen beroepen plaats.

Hubbard (2003) laat in zijn casestudie zien dat informatietechnologie complementaire effecten heeft op de productiviteit van vrachtwagenchauffeurs. Met de komst van computertechnologie aan boord van vrachtwagens is de efficiency flink gestegen. Computers bieden verdergaande mogelijkheden om vrachtwagens te monitoren en zo de opdrachten efficiënter te verdelen tussen chauffeurs die zich op verschillende plaatsen in het land bevinden. Hierdoor worden de routes van chauffeurs efficiënter. Bovendien rijden ze een groter deel van hun werktijd met lading.

Levy (2008) beschrijft de impact van ICT op het werk van radiologen. Computertechnologie zorgt voor snellere en beter leesbare scans. Radiologen kunnen op die manier per dag meer scans lezen. De informatievoorzieningen verlagen bovendien de benodigde kennis voor het lezen van scans. Communicatietechnologie vergroot de markt van radiologen; radiologen in andere werelddelen kunnen gemakkelijk aansluiten om scans te beoordelen. ICT heeft dus de efficiëntie en de concurrentie op de markt van scans vergroot. De prijs van scans daalt hierdoor. Radiologen proberen zich te profileren door zich te specialiseren op bepaalde gebieden van het lichaam of specifieke aandoeningen.

Binnen een bedrijf kan het effect van ICT verschillend uitpakken voor verschillende werknemers en afdelingen. Fernandez (2001) brengt de ontwikkelingen na het vervangen van de technologie in een chocoladefabriek in kaart. Om de overgang te verzachten beloofde het managementteam baan- en loonbehoud aan alle werknemers. Voor alle werknemers leidde de overgang tot een verhoging van de eisen die aan hen werden gesteld. De loonongelijkheid steeg echter ook met de komst van de nieuwe technologie, doordat sommige werknemers werden gekoppeld aan taken die productiever konden worden uitgevoerd door gebruik te maken van ICT.

Groot en De Grip (1991) en Autor en collega's (2002) laten zien dat ICT een verschillend effect kan hebben op afdelingen binnen een bedrijf. Het automatiseren van taken leidde tot verschillende vormen van reorganisatie bij grote banken. Op de afdeling die deposito's afhandelt, vond specialisatie plaats, terwijl medewerkers op de afdeling die speciale gevallen afhandelt juist meer generalist werden. De afweging tussen coördinatie- en productiekosten viel dus anders uit op deze twee afdelingen binnen hetzelfde bedrijf.

In de boeken van Brynjolfsson en McAfee (2011, 2014) komen robots aan bod. Robots nemen op dit moment veel routinematig werk over van de mens, zoals sorteerwerk in magazijnen. Door de ontwikkelingen op het terrein van cameratechnologie krijgt de robot als het ware ogen, waardoor ook andere taken binnen bereik komen. Vooralsnog is hier echter nog geen goed empirisch houvast om de ontwikkelingen richting toekomst te kunnen duiden. 


\section{Arbeidsmarkttrends}

Het monitoren van veranderingen in de verdeling van werk op een gedetailleerd niveau is voor Nederland steeds beter mogelijk. Allereerst door nieuwe databases die het op meer macro-economisch niveau mogelijk maken om ontwikkelingen tussen landen over een wat langere tijdsperiode te vergelijken. Daarnaast zijn er in Nederland ook nieuwe bronnen beschikbaar gekomen die de analyse van consistente trends vanaf het begin van de jaren negentig mogelijk maken. Uit deze databronnen kan de voorzichtige conclusie worden getrokken dat de arbeidsmarktontwikkelingen in Nederland niet anders lijken te zijn dan die in andere landen, maar dat de bewegingen in lonen en werkgelegenheid niet altijd even sterk lijken te zijn als in andere landen.

\subsection{Internationale vergelijking}

In figuur 2 (gebaseerd op gegevens uit Michaels, Natraj en Van Reenen (2014)) zijn landen gesorteerd op de toename van het aandeel van hoogopgeleiden in de totale loonsom (een indicator voor de vraag naar arbeid) in de periode 1980-2004. De volgorde geeft aan dat dit aandeel in de Verenigde Staten en het Verenigd Koninkrijk sterk is toegenomen en dat dit ook geldt voor Nederland en Finland. De groep laagopgeleide werknemers verliest vooral inkomensaandelen in het Verenigd Koninkrijk, Finland en Spanje, waar het aandeel van laagopgeleiden in de totale loonsom met bijna een derde is gedaald.

De landen in figuur 3 (op basis van gegevens uit Goos, Manning en Salomons (2014)) zijn gesorteerd op dalingen in de werkgelegenheid van gemiddeld betaalde banen. In alle landen is de werkgelegenheidsverandering voor banen in het midden negatief, terwijl het aantal banen aan de bovenkant van de loonverdeling groeit. Aan de onderkant van de loonverdeling lijkt er minder dynamiek aanwezig. Het lijkt erop dat er aan de onderkant van de arbeidsmarkt banen zijn bijgekomen, terwijl de lonen daar onder druk staan. In Nederland is de dynamiek het geringst. In ons land groeit de werkgelegenheid van banen aan de bovenkant en onderkant van de loonverdeling met ruim 2 procentpunt in de periode 1998-2010. De werkgelegenheid in het midden daalt met 4,5 procentpunt in deze periode.

De analyses uitgevoerd in het onderzoek van Michael en anderen (2014) relateren deze veranderingen direct aan de opkomst van ICT in de afgelopen dertig jaar. Zij vinden sterke en significante correlaties tussen ICT-investeringen en de toenemende vraag naar hoger opgeleiden en de dalende vraag naar mensen met een middelbare opleiding. De ontwikkelingen aan de onderkant zijn tot nu toe minder geprononceerd, omdat laaggeschoolden enerzijds te maken hebben gehad met het automatiseren van routinematige taken, maar anderzijds ook in beroepen werken met niet-routinematige taken, zoals autorijden en schoonmaken. Het netto-effect op macro-economisch niveau is ongeveer 0. Figuur 4 vat deze analyses samen door de correlaties van de verandering in de loonsom van hoogopgeleide en middelbaar opgeleide werknemers en ICT-investeringen per sector te plotten. De correlaties zijn gebaseerd op dezelfde elf landen die in figuur 2 zijn getoond en zijn duidelijk negatief voor mensen met een middelbare opleiding. Dezelfde correlatie 


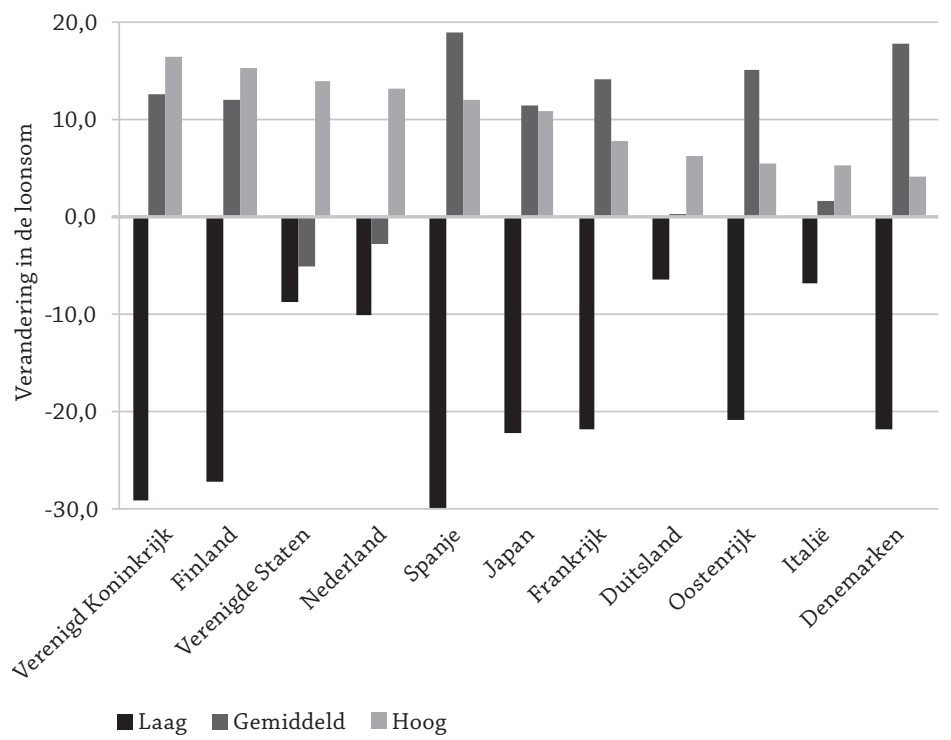

Noot: De landen zijn gesorteerd op de verandering van de loonsom van hoogopgeleiden, waarbij het land met de grootste verandering links staat. De periode is 1980-2004.

Bron: Michaels e.a. (2014)

\section{Figuur 2 Hoogopgeleiden verdienen een steeds groter deel van het inkomen}

voor hoogopgeleiden is positief. De patronen in figuur 4 laten een daling van de vraag naar gemiddeld opgeleide werknemers zien en een stijging van de vraag naar hoogopgeleiden.

\subsection{Nederland onder de loep}

Naast de internationale context is het mogelijk wat gedetailleerder te kijken naar wat er in Nederland in het afgelopen decennium is gebeurd. Bij de middengroep wordt vaak gedacht aan mensen met een mbo-diploma. Dat is een groep van ongeveer 4 miljoen mensen en daarmee ongeveer de helft van de beroepsbevolking. Binnen deze groep bestaat heterogeniteit. Mensen met een mbo4-diploma zijn moeilijk te vergelijken met mensen met een mbo1-diploma (gedefinieerd als vmbo, mbo1 en avo-onderbouw).

Figuur 5 laat zien dat het aantal mensen met een mbo4-diploma op de Nederlandse arbeidsmarkt gestaag toeneemt, terwijl het aantal mensen met een mbo1of mbo2/3-opleiding daalt. Het aantal mensen met alleen basisonderwijs en het aantal mensen met een mbo1- of mbo2/3-opleiding daalt tot 2,9 miljoen (1996-2010). Daar waar in 1996 de grootste groep in de arbeidsmarkt bestond uit mensen met een mbo1- of mbo2/3-opleiding, is op dit moment het aantal 


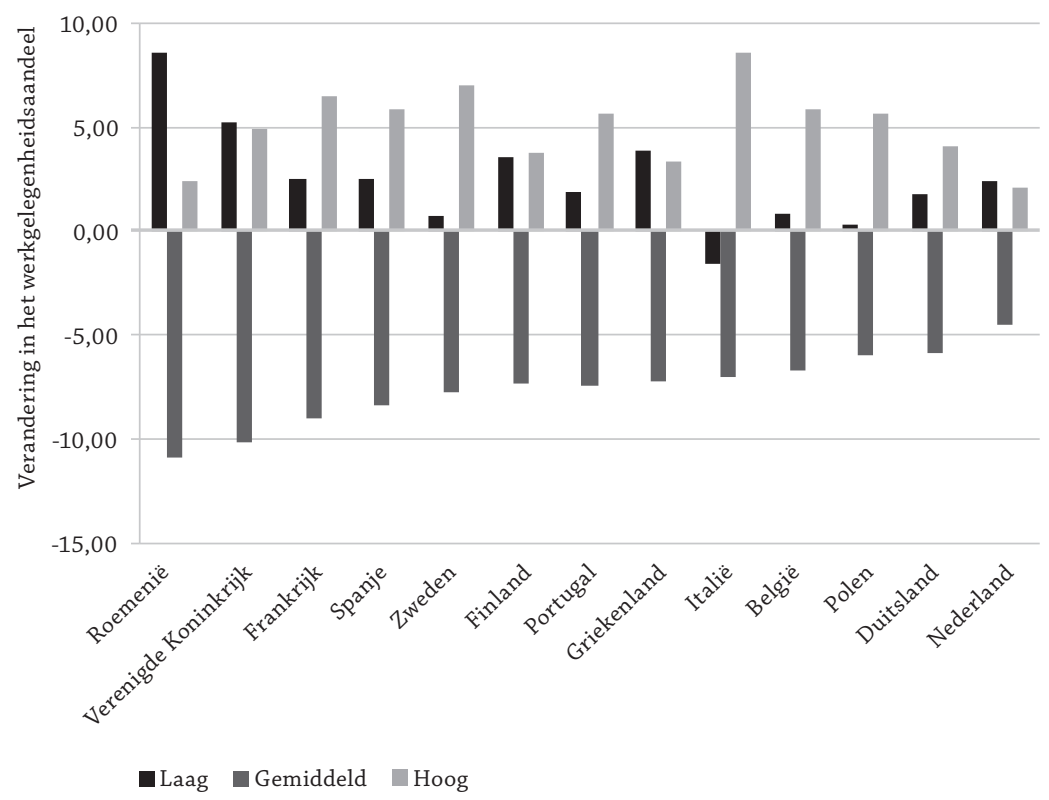

Noot: De landen zijn gesorteerd op de verandering van het werkgelegenheidsaandeel van gemiddeld betaalde banen, waarbij het land met de grootste daling links staat. De periode is 1998-2010.

Bron: Goos e.a. (2014)

Figuur $3 \quad$ Werkgelegenheid in het midden van de arbeidsmarkt neemt af, terwijl werkgelegenheid voor hoog- en laagbetaald werk toeneemt

mensen met een hbo- of mbo4-opleiding het grootst. Het aantal mensen met een mbo4-opleiding is gestegen van bijna 1,2 miljoen naar ruim 1,5 miljoen, wat bijna gelijk is aan de daling van het aantal mensen met een lagere opleiding. Tegelijkertijd is het aantal mensen met een hbo- of wo-opleiding gestegen met bijna 1 miljoen tot 2,6 miljoen. Dit betekent dat de instromende jongeren een hoger opleidingsniveau hebben dan de uitstromende ouderen of mensen die om andere redenen de arbeidsmarkt verlaten.

Figuur 6 geeft de dynamiek weer op de Nederlandse arbeidsmarkt in de periode 1999-2014. Op de horizontale as worden alle beroepen (gemeten op 3-digitniveau) gerangschikt op het gemiddelde loon in 1999. Dit wordt weergegeven aan de hand van 100 percentielen, waarbij het minst verdienende beroep helemaal links staat, het mediane beroep in het midden en het best verdienende beroep rechts. Op de verticale as wordt de verandering in het aandeel van het beroep in de Nederlandse werkgelegenheid gemeten. Alle punten tellen dus op tot 0 , omdat de winst van het ene beroep het verlies van het andere is. De figuur geeft de verandering voor de gehele werkgelegenheid in Nederland weer. Het blijkt dat beroepen in het midden van de loonverdeling in 1999 een negatieve groei van de werkgelegenheid kennen. Omgekeerd, de groei in werkgelegenheid vindt plaats in 

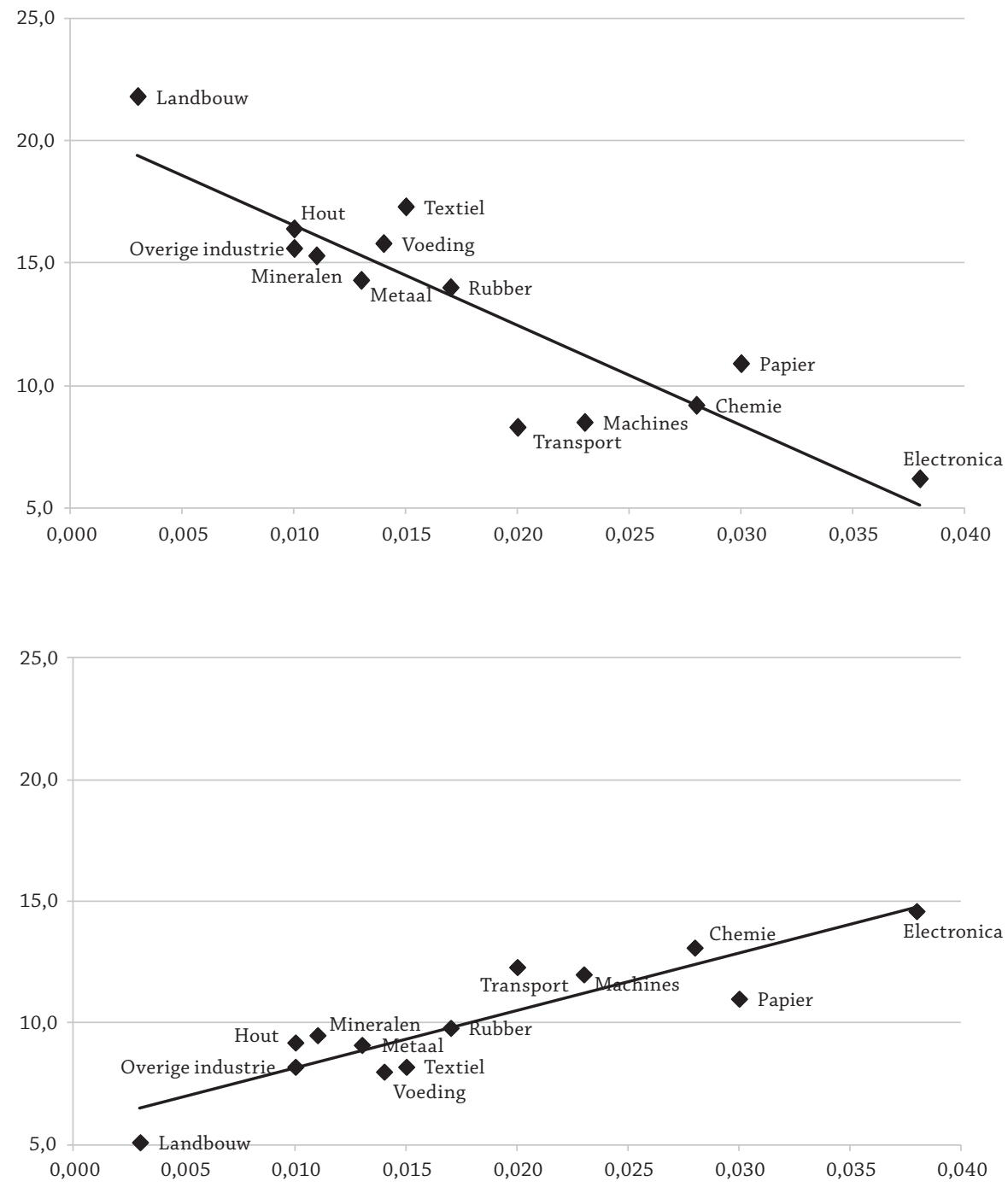

Noot: Deze analyse is op basis van dezelfde landen als weergegeven in figuur 2 . ICT-investeringen zijn gemeten op de horizontale as als investeringen ten opzichte van toegevoegde waarde. Veranderingen in de loonsom zijn gemeten op de verticale as. De periode is 1980-2004.

Bron: Michaels e.a. (2014)

Figuur 4 Technologie-investeringen gaan samen met een dalende vraag naar gemiddeld opgeleide werknemers (links) en een stijgende vraag naar hoogopgeleiden (rechts) 


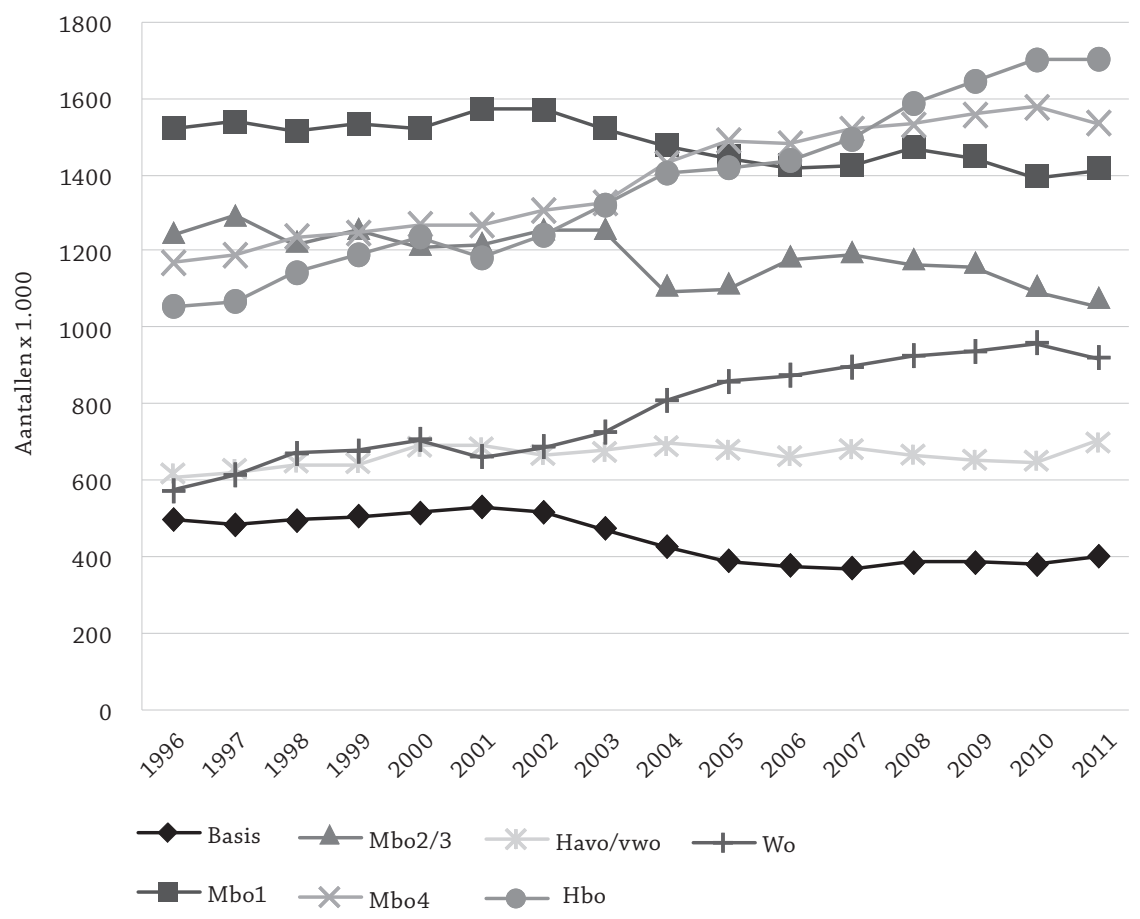

Bron: CBS, Enquête Beroepsbevolking

\section{Figuur 5 De Nederlandse beroepsbevolking is steeds hoger opgeleid, 1996-2011}

beroepen die in 1999 tot de slechtst en de best betaalde banen behoorden. De werkgelegenheidsdaling is het grootst tussen het 20ste en 60ste percentiel van de loonverdeling. Werknemers in deze beroepen hebben relatief vaak een mbo2/3opleiding.

Wanneer we ten slotte de werkloosheid in de periode 1996-2010 bekijken, zien we eenzelfde patroon. Figuur 7 geeft aan dat de werkloosheid relatief laag is onder mbo4 en hoger en hoog onder mbo2/3 en lager. Tot de beginjaren van deze eeuw zijn er drie groepen te onderscheiden: mensen met alleen een basisopleiding zijn het vaakst werkloos, een middengroep die bestaat uit mensen met een mbo1of havo-/vwo-opleiding zijn iets minder vaak werkloos, en mensen met een opleiding daarboven zijn het minst vaak werkloos. Vanaf 2002 lijken de arbeidsmarktkansen voor werknemers met een mbo2/3-opleiding minder gunstig te zijn geworden. 


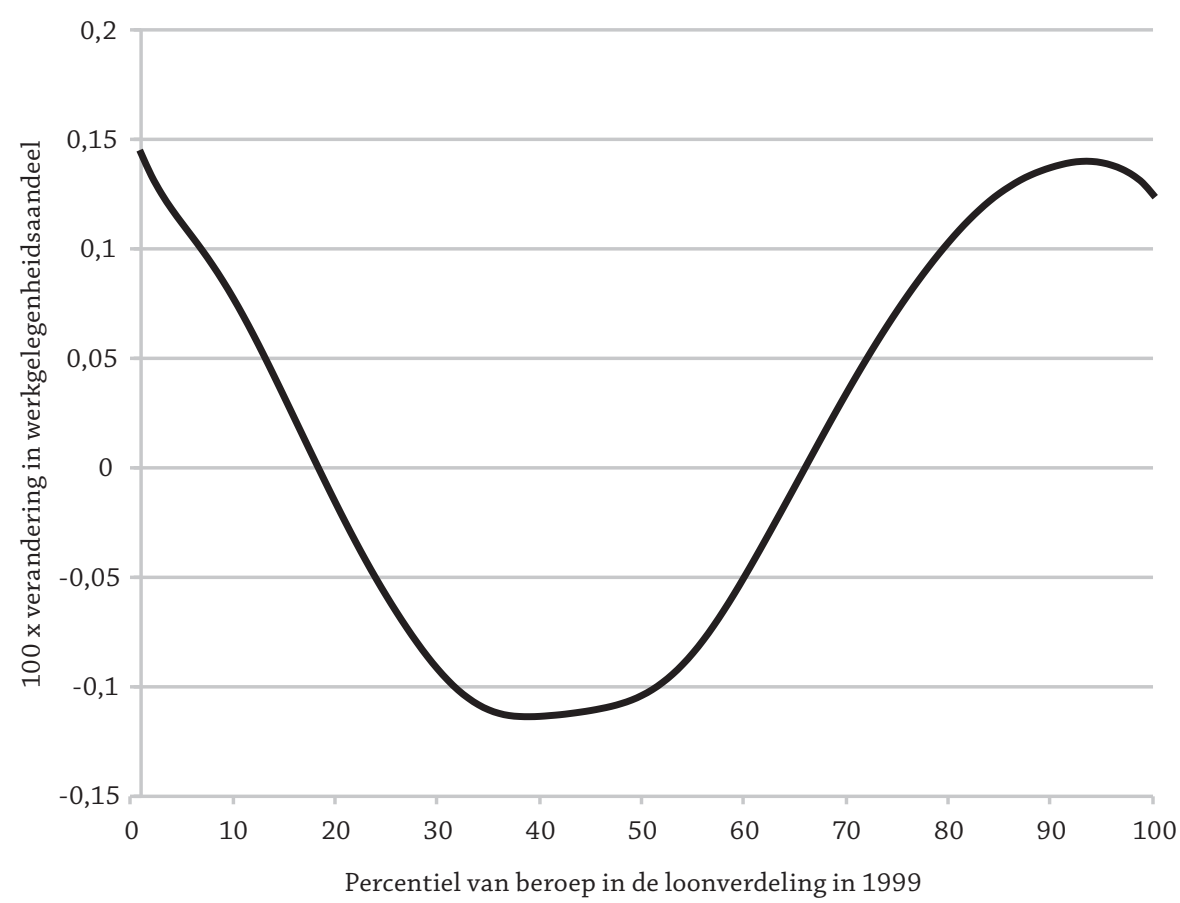

Bron: CBS, Enquête Beroepsbevolking

\section{Figuur 6 Polarisatie van arbeidsmarktkansen in Nederland, 1999-2014}

\section{Conclusie}

Loonongelijkheid in Nederland en in andere landen neemt toe, waardoor hoogopgeleide werknemers verder uitlopen op de rest. Tegelijkertijd dalen de baankansen van mensen met een gemiddeld opleidingsniveau. In de afgelopen decennia is de vraag naar hoogopgeleide werknemers nog sneller gestegen dan het al fors toegenomen aanbod. De relatieve lonen en de kans op de arbeidsmarkt van deze groep werknemers zijn dan ook verder gestegen. De arbeidsmarktpositie van mensen met een mbo-opleiding verslechtert. De werkgelegenheid aan de onderkant is relatief stabiel, maar lonen staan daar wel onder druk.

De consensus in de literatuur is dat de drijvende kracht achter deze trends technologische ontwikkeling is. Als gevolg van computertechnologie is een deel van het werk geautomatiseerd. Het lijkt hier vooral te gaan om routinematig werk dat door laagopgeleiden werd gedaan, maar ook steeds vaker door mensen met een mbo-opleiding. Deze ontwikkelingen veranderen de vraag naar taken en vaardigheden, wat leidt tot veranderingen in prijzen en hoeveelheden. Op dit moment lijkt de arbeidsmarkt zich in een aanpassingsproces te bevinden met neerwaartse 


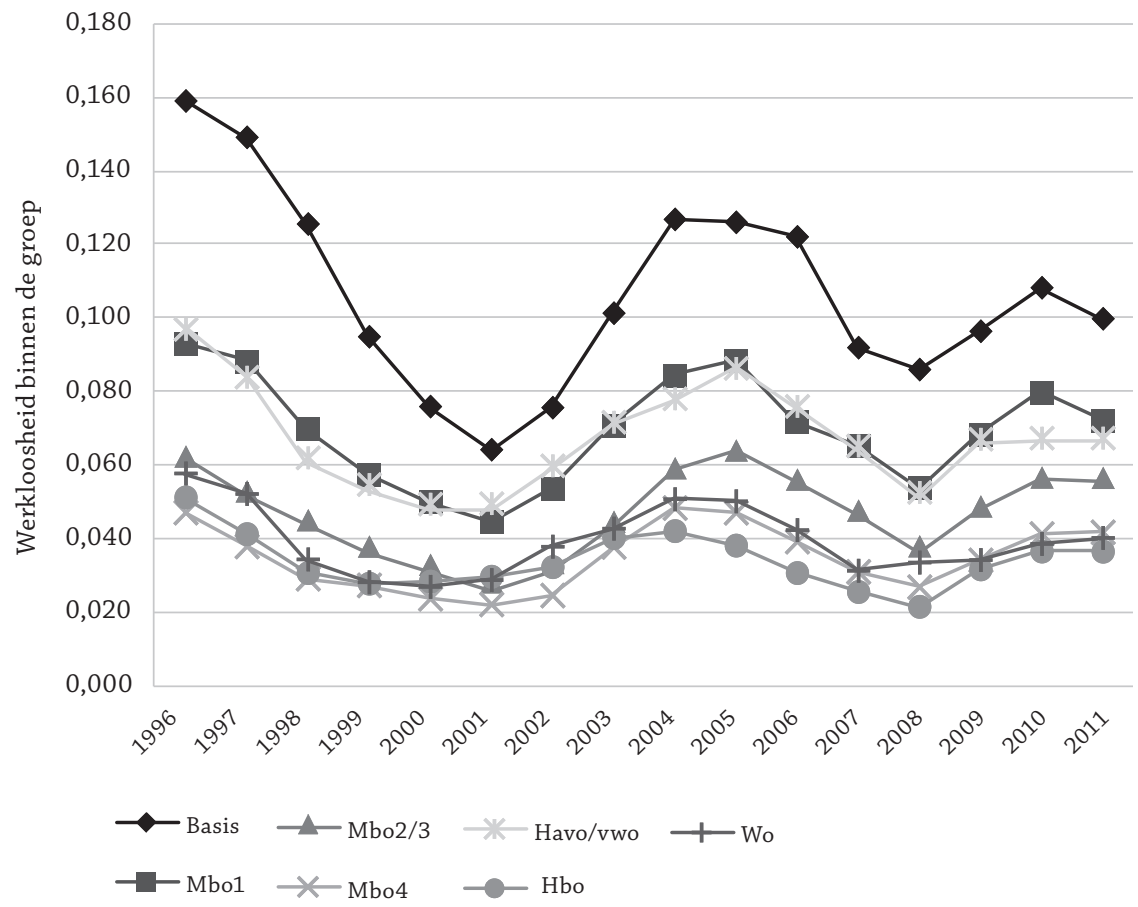

Bron: CBS, Enquête Beroepsbevolking

\section{Figuur 7 Werkloosheid naar opleiding in Nederland, 1996-2011}

dynamiek in het midden van de loonverdeling en in mindere mate aan de onderkant.

Dit betekent niet dat er geen hoop is. Integendeel, nieuwe technologie verhoogt de productiviteit en gaat samen met een toename van de werkgelegenheid. Zo ontstaan er nieuwe banen en problemen die voor werkgelegenheid zorgen. Er wordt soms geopperd dat het verhogen van het onderwijsniveau zinloos is, omdat veel banen voor mbo-opgeleiden zullen verdwijnen, waardoor slechts vraag overblijft naar mensen met een basisopleiding of een universitair diploma. In tijden waarin de opbrengsten van (hoger) onderwijs stijgen, is het echter zaak om alles op alles te zetten om kinderen zo goed mogelijk op te leiden om de nieuwe mogelijkheden te kunnen aangrijpen voor een succesvolle carrière. De trends vanaf 1996 laten zien dat de Nederlandse beroepsbevolking hoger opgeleid is en dat het aanbod van mensen met een lagere mbo-opleiding eerder daalt dan stijgt, terwijl het aantal hbo'ers groeit. 


\section{Noten}

1 Zie Goldin en Katz (2008) en Katz en Margo (2013) en de literatuur en voorbeelden die zij bespreken voor een historisch overzicht van de veranderingen in werkgelegenheid als gevolg van technologische verandering.

2 Zie bijvoorbeeld Acemoglu en Autor (2011) en Autor (2014) voor overzichtsstudies die vooral de ontwikkelingen in de Verenigde Staten duiden, en Machin en Van Reenen (1998), Hollanders en Ter Weel (2002), Goos e.a. (2014) en Michaels e.a. (2014) voor internationaal vergelijkende studies.

3 Zie de bijdragen van Brynjolfsson en McAfee (2011, 2014) voor overzichten van de mogelijke implicaties van robots voor de arbeidsdeling tussen mens en machine.

4 Zie Becker en Murphy (1992), Autor, Katz en Krueger (1998), Bresnahan, Brynjolfsson en Hitt (2002), Autor e.a. (2003), Borghans en Ter Weel (2004, 2006) en Akçomak, Borghans en Ter Weel (2011) voor de formele uitwerking van deze argumenten.

5 Er zijn verschillende manieren om werktaken te classificeren. Zie Autor en Handel (2013) en Ter Weel en Kok (2013) voor een bespreking van de alternatieven.

\section{Literatuur}

Acemoglu, D., \& Autor, D.H. (2011). Skills, tasks and technologies: Implications for employment and earnings. In: O. Ashenfelter \& D.E. Card (Eds.), Handbook of Labor Economics (vol. 4). Amsterdam: Elsevier, 1043-1171.

Akçomak, I.S., Borghans, L., \& Weel, B. ter (2011). Measuring and interpreting trends in the division of labour in the Netherlands. De Economist, 159 (4): 435-482.

Autor, D.H. (2014). Skills, education, and the rise of earnings inequality among the 'other 99 percent'. Science, 344 (6186): 843-851.

Autor, D.H., \& Handel, M. (2013). Putting tasks to the test: Human capital, job tasks and wages. Journal of Labor Economics, 31 (supplement), S1-S16.

Autor, D.H., Katz, L.F., \& Kearney, M.S. (2006). The polarization of the US labor market. American Economic Review, 96 (2): 189-194.

Autor, D.H., Katz, L.F., \& Krueger, A. (1998). Computing inequality: Have computers changed the labor market? Quarterly Journal of Economics, 113 (4): 1169-1214.

Autor, D.H., Levy, F., \& Murnane, R.J. (2002). Upstairs, downstairs: Computers and skills on two floors of a large bank. Industrial \& Labor Relations Review, 55 (3): 432-447.

Autor, D.H., Levy, F., \& Murnane, R.J. (2003). The skill content of recent technological change: An empirical investigation. Quarterly Journal of Economics, 118 (4): 1279-1333.

Becker, G.S., \& Murphy, K.M. (1992). The division of labor, coordination costs and knowledge. Quarterly Journal of Economics, 107 (4): 1137-1160.

Borghans, L., \& Weel, B. ter (2004). What happens when agent $T$ gets a computer? The labor market impact of cost efficient computer adoption. Journal of Economic Behavior \& Organization, 54 (2): 137-151.

Borghans, L., \& Weel, B. ter (2006). The division of labour, worker organisation and technological change. Economic Journal, 116 (509): F45-F72.

Bresnahan, T., Brynjolfsson, E., \& Hitt, L. (2002). Information technology, workplace organization, and the demand for skilled labor: firm level evidence. Quarterly Journal of Economics, 117 (1): 339-376. 
Brynjolfsson, E. \& McAfee, A. (2011). Race Against the Machine. How the Digital Revolution is Accelerating Innovation, Driving Productivity, and Irreversibly Transforming Employment and the Economy. Lexington: Digital Frontier Press.

Brynjolfsson, E., \& McAfee, A. (2014). The Second Machine Age: Work, Progress, and Prosperity in a Time of Brilliant Technologies. New York: W.W. Norton \& Company.

Butter, F. den, \& Mihaylov, E. (2013). Veranderende vaardigheden op de Nederlandse arbeidsmarkt. Economisch Statistische Berichten, 98 (4670): 618-621.

Fernandez, R. (2001). Skill-biased technological change and wage inequality: Evidence from a plant retooling. American Journal of Sociology, 107 (2): 273-320.

Goldin, C., \& Katz, L.F. (2008). The Race between Education and Technology. Cambridge: Harvard University Press.

Goos, M., \& Manning, A. (2007). Lousy and lovely jobs: The rising polarization of work in Britain. Review of Economics and Statistics, 89 (1): 118-133.

Goos, M., Manning, A., \& Salomons, A. (2014). Explaining job polarization: Routine-biased technological change and offshoring. American Economic Review, 104 (8): 2509-2526.

Groot, L.F.M., \& Grip, A. de (1991). Technological change and skill formation in the bank sector. Economics of Education Review, 1: 57-71.

Hollanders, H., \& Weel, B. ter (2002). Technology, knowledge spillovers, and changes in employment structure: Evidence from six OECD countries. Labour Economics, 9 (5): 579-599.

Hubbard, T. (2003). Information, decisions, and productivity: On-board computers and capacity utilization in trucking. American Economic Review, 93 (4): 1328-1353.

Katz, L.F., \& Margo, R.A. (2013). Technical change and the relative demand for skilled labor: The United States in historical perspective (NBER Working Paper No. 18752).

Levy, F. (2008). Computers and the supply of radiology services: The anatomy of a disruptive technology. Journal of the American College of Radiology, 5 (10): 1067-1072.

Machin, S.J., \& Reenen, J. van (1998). Technology and changes in skill structure: Evidence from seven OECD countries, Quarterly Journal of Economics, 113 (4): 1215-1244.

Michaels, G., Natraj, A., \& Reenen, J. van (2014). Has ICT Polarized Skill Demand? Evidence from Eleven Countries over 25 Years. Review of Economics and Statistics, 96 (1): 60-77.

Spitz-Oener, A. (2006). Technical change, job tasks, and rising educational demands: Looking outside the wage structure. Journal of Labor Economics, 24 (2): 235-270.

Timmer, M.P., Azeez Erumban, A., Los, B., Stehrer, R., \& Vries, G.J. de (2014). Slicing up global value chains. Journal of Economic Perspectives, 28 (2): 99-118.

Weel, B. ter, \& Kok, S. (2013). De Nederlandse arbeidsmarkt in taken: eerste bevindingen uit de Nederlandse Skills Survey (CPB Boek nr. 8). Zie www.cpb.nl/publicatie/de-nederlandsearbeidsmarkt-in-taken-eerste-bevindingen-uit-de-nederlandse-skills-survey. 